\title{
The Microorganisms in the Portuguese National Curriculum and Primary School Textbooks
}

\author{
Paulo Mafra ${ }^{*}, 1,3$, Nelson Lima ${ }^{2,3}$ \\ ${ }^{1}$ Department of Natural Sciences, ESE of Bragança, Campus de Santa Apolónia - Apartado 1101-5301-856 \\ Bragança, Portugal \\ ${ }^{2}$ DCILM, Institute of Child Studies, Campus de Gualtar, University of Minho, 4710-057 Braga, Portugal \\ ${ }^{3}$ LIBEC/CIFPEC, Campus de Gualtar, University of Minho, 4710-057 Braga, Portugal \\ *Corresponding author: e-mail: pmafra@iol.pt, Phone: +351919239722
}

\begin{abstract}
The main aim of the present work is the content analysis of the Portuguese National Curriculum and the Primary School textbooks where microorganisms are concerned. The content analysis through categories created a priori were used as methodology. In all analysed documents the topic microorganisms did not emerge in a clear way. However, several indirect themes related to microorganisms were found in the National Curriculum and textbooks of the Environment Study issue. These themes can be explored with pupils through experimental activities. The Science Education in primary schools can be introduced with proposals of activities involving microorganisms and contributing to a better understanding of the children's world.
\end{abstract}

Keywords Textbooks analysis; Microorganisms; Primary School

\section{Introduction}

From an early age children are told about microorganisms. The concept about microorganisms is ordinarily developed in the children because of the diseases that they or their parents and relatives normal experience. In this way, the concept about these intangible living organisms is naturally coined negatively. Besides this blurred and negative representation it is important that children know the other-side of microorganisms; in general the recognition of the importance of these living organisms to their life and to the planet. It is also important that they discover some of essential and tangible roles that microorganisms play in the world like in production of different kinds of food, in the environment, industry, and in health when helping us fight diseases with antibiotics.

We carry out this research in order to answer the following question: Are the Portuguese National Curriculum and the Primary School textbooks concerned with the plurality of activities of microorganisms? To answer this research question we took into consideration that the textbooks are a didactic resource both to teachers, who use them as a guide in the classroom and to students whose textbooks are, for most of them, the only way of accessing science (Silva, 2001). So, the National Curriculum and textbooks of Primary School became the preferential source to carry out our research, through the content analysis. Using this technique for making inferences by objectively and systematically identifying specified characteristics of messages, we expected to get a better understanding of the contents and concepts that the Portuguese Primary School has about microorganisms. This survey is an essential approach if we want to develop a coherent and applicable action plan to initiate teaching microbiology in the Primary Schools.

\section{Methodology}

Sixteen textbooks of Environment Study of Primary School [M1-16] (from the $1^{\text {st }}$ to the $4^{\text {th }}$ grades), which included 4 publishers for each grade, were selected to be analysed. The National Curriculum of Primary School (Ministry of Education, 2004) was also analysed.

To carry out the analysis of the texts and images of the textbooks a priori categories of analysis were defined. In more detail, for the text analysis two categories were defined as presented in Table 1. 
Table I - Categories of the analysis of the text in textbooks

\begin{tabular}{|l|l|l|}
\hline \multicolumn{1}{|c|}{ Category } & \multicolumn{1}{|c|}{ Definition } & \multicolumn{1}{|c|}{ Example } \\
\hline Informative & $\begin{array}{l}\text { Text that just means to inform about } \\
\text { a content spreading facts and } \\
\text { concepts. }\end{array}$ & $\begin{array}{l}\text { "...skin covers our body protecting } \\
\text { it from the entrance of germs and } \\
\text { impurities ..." }\end{array}$ \\
\hline Explanatory & $\begin{array}{l}\text { Text in which facts are presented but } \\
\text { followed by an attempt to explain } \\
\text { their meaning. }\end{array}$ & $\begin{array}{l}\text { Vaccines prosines are very important. } \\
\text { diseases..." protect us from }\end{array}$ \\
\hline
\end{tabular}

The Portuguese textbooks for primary schools are intensively illustrated. In order to get all information that each image contained, they were analysis using the criteria defined by Drouin (1987), Amador and Carneiro (1999) and Palma (2005). Table II presents the three categories used and their definitions.

Table II - Categories of the analysis of the images in textbooks

\begin{tabular}{|l|l|}
\hline \multicolumn{1}{|c|}{ Category } & \multicolumn{1}{|c|}{ Definition } \\
\hline Semiology of images & The image can be classified through photography, drawing or scheme. \\
\hline Pedagogy of images & $\begin{array}{l}\text { Know the role of the image in the text to see if its function is to motivate, } \\
\text { help the memorization or even if it has an aesthetic, explanatory and } \\
\text { metalinguistic function. }\end{array}$ \\
\hline Image and conception & $\begin{array}{l}\text { Know if the image transmits a visualization of the mentioned concepts. In } \\
\text { this case, this category will not be used due to the fact that the content is } \\
\text { not explicit in the curriculum and in textbooks. Therefore, conception will } \\
\text { always be present in a broader way in the analysis through the study (and } \\
\text { not only through the images) in the search of signs which indicate the } \\
\text { possibility of exploration of the microorganisms themes in the Primary } \\
\text { School. }\end{array}$ \\
\hline
\end{tabular}

Finally, in what microorganisms are the contents of the National Curriculum of Primary School concerned and its related documents were analysed taking into account the following four parameters:

1- Microorganisms as a part of the living world (e.g. biological diversity, the Kingdoms, classification of living organisms);

2- Microorganisms and health (e.g. vaccines, diseases, hygiene of the body, food and places);

3- Microorganisms and food (e.g. production; time of shelf-life, food transformation and preservation);

4- Microorganisms in industry, technology and environment (e.g. treatment of wastewater and pollution).

\section{Results and Discussion}

The topic Microorganisms is not directly observed and mentioned in textbooks or in the National Curriculum of Primary School. What it was found is that this topic appears indirectly or implicitly being in some issues associated with the curriculum. Indirectly or implicitly means references in curriculum and textbooks contents which are related to microbial activities. Table III summarised the issues in the National Curriculum of Primary School in which was consider to have any relation with microorganisms.

The microorganism's topic also appears in textbooks indirectly. In this case it is related with health/hygiene, food and environment contents. To illustrate the findings, some examples of contents that we have found in textbooks related with analysis parameters along the four grades will be presented next. 
Table III - Issues of the National Curriculum of Primary School where the topic "microorganisms" is indirectly mentioned

\begin{tabular}{|c|c|c|}
\hline Grade & Set of the Curriculum & Thematic \\
\hline $1^{\text {st }}$ & $\begin{array}{l}\text { Set } 3 \text { - Knowing the natural environment } \\
\text { Point } 1 \text { - The living organisms and their environment. }\end{array}$ & $\begin{array}{l}\text { Identification of the rules of body and food hygiene: wash } \\
\text { hands before eating, brush the teeth, wash the food; the } \\
\text { knowledge and application of the rules of supervision of } \\
\text { his/her health (going periodically to the physician, } \\
\text { individual health record) } \\
\text { Showing animal and vegetable's life (identification of plants } \\
\text { and animals and their relating environment). }\end{array}$ \\
\hline $2^{\text {nd }}$ & $\begin{array}{l}\text { Set } 1-\text { Knowing yourself } \\
\text { Point } 4 \text { : Your body's health } \\
\text { Set } 3 \text { - Knowing the natural environment } \\
\text { Point } 1 \text { - The living organisms and their environment. }\end{array}$ & $\begin{array}{l}\text { Habits of daily hygiene, importance of potable water, expiry } \\
\text { date of food, hygiene of places of collective use; recognition } \\
\text { of the importance of vaccination to the health. } \\
\text { Showing animal and vegetable's life (identification of plants } \\
\text { and animals and their relating environment). }\end{array}$ \\
\hline $3^{\text {rd }}$ & $\begin{array}{l}\text { Set } 4 \text { - Knowing the inter-relationship between places. } \\
\text { Point 5: The local trade. } \\
\text { Set } 5 \text { - Knowing materials and objects } \\
\text { Point 4: Handling objects in concrete situations } \\
\text { Set } 6 \text { - Knowing the inter-relationship between nature } \\
\text { and society. } \\
\text { Point } 1 \text { : Agriculture and the environment. } \\
\text { Point 2: Cattle creation in local environment. } \\
\text { Point 4: Fishing activity. } \\
\text { Point } 8 \text { : Buildings in local environment. }\end{array}$ & $\begin{array}{l}\text { Making experiences and observing reproduction of plants, } \\
\text { identifying factors of the environment which restrict animals } \\
\text { and plants' life. } \\
\text { Use criteria to compare and classify plants. } \\
\text { How food is conserved, storage and handling conditions. } \\
\text { Expiry date of food. } \\
\text { Microscope handling. } \\
\text { Agriculture as source of stocks (wheat/flour, grapes/wine, } \\
\text { tomato/tomato paste). } \\
\text { Production of dairy products and cured sausage. } \\
\text { Canned food. } \\
\text { Importance of basic sanitation and water storage for human } \\
\text { populations. }\end{array}$ \\
\hline $4^{\text {th }}$ & $\begin{array}{l}\text { Set 1-Knowing yourself } \\
\text { Point 1: Your body's health } \\
\text { Point 2: The safety of your body } \\
\text { Set 5-Knowing materials and objects } \\
\text { Point 4: Handling objects in concrete situations } \\
\text { Set 6-Knowing the inter-relationship between nature } \\
\text { and society. } \\
\text { Point 1: Main national productive activities. } \\
\text { Point 2: The environment quality. }\end{array}$ & $\begin{array}{l}\text { Identification of skin protective function. } \\
\text { Know the basic first-aid rules. } \\
\text { Microscope handling. } \\
\text { Identification of products of the Portuguese industry: canned } \\
\text { food, etc. } \\
\text { Identification of polluting factors, water quality and ways of } \\
\text { pollution in water streams, environmental instability forced } \\
\text { by human activity. }\end{array}$ \\
\hline
\end{tabular}

\subsection{Results and discussion by parameter of analysis}

\subsubsection{Parameter 1 - Microorganisms as a part of the living world}

Microorganisms are not referred to as making part of the living world neither in the National Curriculum of Primary School nor in the analysed textbooks. In the syllabus set in which it could be more directly mentioned Knowing the natural environment - we pointed out that the representativeness of the living world is exclusive for animals and plants. Nevertheless, in textbooks M4 to M9 the word "germs" emerges infrequently, however without any association with the living world.

In this parameter of analysis an old scientific concept, which is actually unacceptable, defined mushrooms as plants [M6, 7 and 10]. This confirms the narrow vision given to this topic. The contents related with microorganisms appear in the text in an informative way and the images are shown by photo or drawing with a motivating or metalinguistic function. 


\subsubsection{Parameter 2- Microorganisms and health}

Under this parameter, the body care emerges as the main topic followed by drawings of children having a bath and brushing their teeth, which predominantly has an explanatory function.

The approach to the vaccines topic usually has an informative nature. However, in M4 we found a picture of a child smiling followed by a text that clearly has a motivating function: "vaccines are very important. Vaccines protect us from diseases". This text has an explanatory function, showing the reason why vaccines are important. Another occurrence was found in M2, in which there is a drawing that shows a child who had been vaccinated playing with a healthy appearance. In contrast, we can observe another child with an ill appearance and who has previously refused to take the vaccines. This picture has a metalinguistic function since no text was found to explain it. In other words, it means that the picture needs to be understood by the students to learn the importance to be vaccinated.

In $4^{\text {th }}$ grade, in the topic concerning the skin function, the word "germ" appears in informative texts. Associated to these texts we found images of a schematic skin with an explanatory function. In this topic we have found an idea that "skin prevents germs from entering in human organism" [M15]. This idea is partly true, however, we did not find complementary information saying that these organisms can enter in our body using other ways.

\subsubsection{Parameter 3 - Microorganisms and food}

Relatively to food production, it is a poorly mentioned topic in $1^{\text {st }}$ grade textbooks; it only appears in some images with a metalinguistic function. However, in $3^{\text {rd }}$ and $4^{\text {th }}$ grades there are clearer associations among some raw materials and the final products: "...corn is used in bread production..." [M13], "...other products derived from milk like yoghurts, cheese and butter" [M14]. Despite the text being always informative, the existing relation between the raw materials and the transformed product is clear; it is also clear the absence of association between microorganisms as agents of the transformation and the final product. The pictures associated to the text appear as photos with a motivating function, because they do not show the transformation process, they only show the raw material and the final product.

Regarding food expiry date (shelf-life time), we have observed informative texts in some photos of food packaged labels where the date is put in evidence (explanatory function): "people should not eat food after the mentioned date" (M5). We have also found explanatory texts: "food goes off, too. It has an expiry date. After that date, it can cause many problems" [M6].

Food preservation is well shown in $3^{\text {rd }}$ grade textbooks. Sentences like “...in order for food not to go off, several preservation processes have been invented. At home we have frozen food, canned food..." [M10] reflect an explanatory nature because they go further when they explain why food must be preserved.

\subsubsection{Parameter 4 - Microorganisms in industry, technology and environment}

In $1^{\text {st }}$ grade textbooks, the information related to this thematic is limited to the appearance of the terms "potable water" and "water pollution", without any explanation. In M6, we found a diagram that represents the course of wastewaters from houses to a structure like a WTP (Wastewater Treatment Plant) and this has clearly a metalinguistic function. The picture also shows an alternative concept because the drawing puts the WTP underneath houses, i.e. in the subsoil.

In $2^{\text {nd }}$ grade, we found references to potable water in informative texts, but also with an explanatory nature: "This water is clean, it has not debris nor germs (...) it is drinkable. It is potable water..." [M8]. This is an attempt to defining potable water. This sentence is related with a figure that represents drawings (taps, water bottles) with an explanatory function.

In $3^{\text {rd }}$ and $4^{\text {th }}$ grades, this theme is focalised in pollution causes (cattle creation and some industries polluted the environment). There are informative texts connected with figures like pictures which show discharges of polluted water by industries in rivers which have an explanatory function. In $4^{\text {th }}$ grade textbooks, there is still a relation between pollution and the appearance of the diseases in animals and plants that involving environment. To illustrate this concept, pictures of dead or weak animals in a polluted environment were found near the text and have an explanatory function.

\section{Further Information}

This study shows that microorganisms are not clearly mentioned in Primary Scholl textbooks or in the National Curriculum. On the other words at this level they are not considered part of the living world. The absence of this topic in National Curriculum of Primary School has the consequence that the theme does not appear structured in textbooks. From a pedagogic point of view it is disturbing that, when microorganisms (germs) are mentioned 
in textbooks, it happens in an incomplete or even wrong way leading to possible didactic obstacles for students (Clément, 1998).

Considering that one of the main aims of the Environment Study is to contribute to a better perception and understanding of the child's involving physical-natural environment, we think this omission can potentially generate wrong conceptions about the living world and it is also a narrow perception of the child's involvement in the physical-natural world.

Through this analysis we have seen that in The Environment Study curriculum and in textbooks there are moments in which the theme "microorganisms" can be explored through experimental activities using negative and positive aspects of their activities. Therefore, studies that focus on this topic can contribute to a better understanding of how microbiology can be initiated at this level and motivate the establishment of experimental activities proposals.

\section{References}

[1] AMADOR, F. e CARNEIRO, H. (1999). O papel das imagens nos manuais escolares de ciências naturais do ensino básico: uma análise do conceito de evolução. Revista de Educação, 8, 119-129.

[2] CLÉMENT, P. (1998). La biologie et sa didactique. Dix ans de recherches. Aster (Paris, INRP), 27, 57-93.

[3] DROUIN, A. M. (1987). Dês images et des sciences. Aster (Paris, INRP), 4, 1-31.

[4] MINISTÉRIO DA EDUCAÇÃO (2004); Organização curricular e programas $-1^{o}$ ciclo do ensino básico (4ª Ed.). DEB, Lisboa.

[5] PALMA, M.I. (2005). Educação Ambiental: a formal e a não formal. Contributos dos centros de recursos de Educação Ambiental para a formação das crianças do $1 .^{\circ}$ Ciclo do Ensino Básico. Tese de Mestrado. Departamento de Ciências Integradas e Língua Materna. Instituto de Estudos da Criança. Universidade do Minho, Braga.

[6] SILVA, J. L. (2001). A Construção do conhecimento em manuais escolares de ciências. In: Congresso GalaicoPortuguês de Psicopedagogia: vol. II, pp. 169-179. Centro de Estudos em Educação e Psicologia da Universidade do Minho, Braga.

\section{Textbooks Used}

[M1] SILVA, C. V. e MONTEIRO, M. L. (2003). Júnior - Estudo do Meio. 1. o ano do Ensino Básico. Texto Editores.

[M2] MARQUES, C. e TIMÓTEO, N. (2003). De flor em flor - Estudo do Meio. 1. ${ }^{\circ}$ ano do Ensino Básico. Gailivro.

[M3] COSTA, A. M. (2005). Crescer com o Meio - Estudo do Meio. 1. ${ }^{\circ}$ ano do Ensino Básico, $3^{\mathrm{a}}$ edição. Edições Nova Gaia.

[M4] MOTA, A. (2004). Caminhar-Estudo do Meio. 1. ${ }^{\circ}$ ano do Ensino Básico, 2. ${ }^{\text {a }}$ edição. Gailivro.

[M5] SILVA, C. V. e MONTEIRO, M. L. (2004). Júnior - Estudo do Meio. 2. ${ }^{\circ}$ ano do Ensino Básico. Texto Editores.

[M6] MONTEIRO, J. e PAIVA, M. (2005). Estudo do Meio do João - Estudo do Meio. 2..$^{\circ}$ ano do Ensino Básico. Gailivro.

[M7] FREITAS, M. e LETRA, C. (2005). Saltitão - Estudo do Meio. 2. ${ }^{\circ}$ ano do Ensino Básico. Gailivro.

[M8] SALGADO, D. e COSTA, T. (2004). Pitágoras e o Meio - Estudo do Meio. 2. ${ }^{\circ}$ ano do Ensino Básico. Edições Nova Gaia.

[M9] MONTEIRO, J. e PAIVA, M. (2005). Estudo do Meio do João - Estudo do Meio. 3. ${ }^{\circ}$ ano do Ensino Básico. Gailivro.

[M10] FREITAS, M. e LETRA, C. (2005). Saltitão - Estudo do Meio. 3. ${ }^{\circ}$ ano do Ensino Básico. Gailivro.

[M11] LEITE, C. e PEREIRA, R. (2005). Aprender a descobrir - Estudo do Meio. 3. ${ }^{\circ}$ ano do Ensino Básico. Edições Nova Gaia.

[M12] BORGES, F., LIMA, J. e FREITAS, M. (1997). Andorinha Turrinha 3 - Estudo do Meio. 3. o ano do Ensino Básico. Porto Editora.

[M13] MONTEIRO, J. e PAIVA, M. (2005). Estudo do Meio do João - Estudo do Meio. 4. ${ }^{\circ}$ ano do Ensino Básico. Gailivro.

[M14] ROCHA, A., LAGO, C. e LINHARES, M. (2006). Amiguinhos - Estudo do Meio. 4. ${ }^{\circ}$ ano do Ensino Básico. Texto Editores.

[M15] MOTA, A. (2005). Caminhar - Estudo do Meio. 4. ${ }^{\circ}$ ano do Ensino Básico, 2..$^{a}$ edição. Gailivro.

[M16] BORGES, F., LIMA, J. e FREITAS, M. (1998). Andorinha Turrinha 4 - Estudo do Meio. 4. ${ }^{\circ}$ ano do Ensino Básico. Porto Editora. 